\title{
Technical Research on Remote Sensing Monitoring of Green Mine
}

\author{
Yang Jinzhong ${ }^{1}$, Zhao Yuling $^{1}$, Yao Weiling ${ }^{1}$ \\ ${ }^{1}$ China Aero Geophysical Survey and Remote Sensing Center for Natural Resources, Beijing
}

\begin{abstract}
This paper proposed primary factors for preliminary screening of candidate mines and annual monitoring of green mines based on integrated analysis on green mine construction requirements, assessment indicators, etc.; introduced technical procedure, work content and work method of monitoring through example analysis, and preliminarily built a technology system for preliminary screening of candidate mines and annual monitoring of green mines.
\end{abstract}

\section{Introduction}

With continuous advancement of ecological civilization construction, promoting green development of mining industry and accelerating green mine construction have become focuses and difficulties in current mining and utilization of mineral resources. Green mine is to implement scientific and orderly mining, control the disturbance over mining area and surrounding ecological environment within a controllable range, and achieve ecologicalization of mining area environment, scientization of mining mode, high efficiency of resources utilization, standardization of enterprise management and harmonization of mining area community in the entire process of mining mineral resources. ${ }^{[1-6]}$ This paper discussed content and method of utilizing remote sensing technology and conducting preliminary screening of candidate mines (hereinafter referred to as "candidate mines"), and annual monitoring of green mines (hereinafter referred to as "green mines"), for the purpose of importing advice and suggestions for establishing a remote sensing monitoring technology system of mature green mine as soon as possible.

\section{Requirements for green mine construction}

According to "The Implementation Opinions of Ministry of Land and Resources of the P.R.C., Ministry of Finance of the P.R.C., Ministry of Environmental Protection of the P.R.C., General Administration of Quality Supervision, Inspection and Quarantine of the P.R.C., and China Banking Regulatory Commission, China Securities Regulatory Commission on Accelerating Green Mine Construction (Ministry of Land and Resources No. [2017]4)" and the green mine construction specifications issued by Ministry of Natural Resources of the People's Republic of China, such as "Green Mine Construction Specification of Onshore Petroleum and Natural Gas Mine" (DZ/T0317-2018), "Green Mine Construction Specification of Coal Industry" (DZ/T0315-2018), etc. ${ }^{[1-}$ ${ }^{6}$, the assessment indicators for green mine construction include multiple factors, such as environmental features of mines, development and utilization mode, intensive and economical utilization of resources, modernization of mine construction, harmony of mineral estate, corporate cultural image, etc. (Table 1)

Moreover, candidate mines and green mines shall be an independent mine with a valid mining license. In recent three years, the mine has not been subject to administrative penalties by the departments related to natural resources and ecological environment, and the mining right owner has not been included in the anomaly list (Table 1). New mine has normally produced for at least one year. Remaining mining years of productive mine shall be no less than five years, and it operates normally. 
Tab.1 Assessment Indicators for Green Mine Construction

\begin{tabular}{|c|c|c|c|c|c|c|c|}
\hline \begin{tabular}{|c|} 
Industrie \\
$\mathrm{S}$
\end{tabular} & Coal & $\begin{array}{l}\text { Petroleum and } \\
\text { natural gas }\end{array}$ & $\begin{array}{c}\text { Non-ferrous } \\
\text { metals }\end{array}$ & Gold & Metallurgy & Chemicals & Non-metal \\
\hline \multirow{4}{*}{ 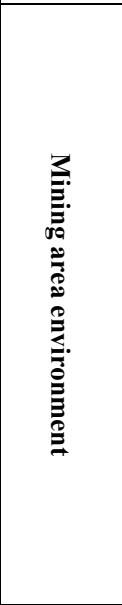 } & \multicolumn{7}{|c|}{$\begin{array}{c}\text { Layout of mining area is reasonable; sign, signboard, etc. are uniform in specifications, clear and handsome; production and living in } \\
\text { mining area are orderly and standardized. }\end{array}$} \\
\hline & $\begin{array}{c}\text { Totally closed } \\
\text { management of } \\
\text { production, } \\
\text { transportation, } \\
\text { storage and ground }\end{array}$ & $\begin{array}{l}\text { Perfect ground } \\
\text { engineering } \\
\text { system and } \\
\text { supporting } \\
\text { facilities, flat } \\
\text { roads and } \\
\text { convenient } \\
\text { transportation } \\
\end{array}$ & $\begin{array}{c}\text { Take measures to } \\
\text { prevent dust during } \\
\text { production, } \\
\text { transportation and } \\
\text { storage }\end{array}$ & $\begin{array}{c}\text { Take measures to } \\
\text { prevent dust during } \\
\text { production, } \\
\text { transportation and } \\
\text { storage }\end{array}$ & $\begin{array}{c}\text { Take measures to } \\
\text { prevent dust during } \\
\text { production, } \\
\text { transportation and } \\
\text { storage }\end{array}$ & $\begin{array}{c}\text { Standardized and } \\
\text { orderly production, } \\
\text { transportation and } \\
\text { stock-piling of } \\
\text { products and } \\
\text { barren rocks }\end{array}$ & $\begin{array}{c}\text { Standardized and } \\
\text { orderly } \\
\text { production, } \\
\text { transportation } \\
\text { and stock-piling } \\
\text { of ores and } \\
\text { barren rocks }\end{array}$ \\
\hline & \begin{tabular}{|c} 
Rain and sewage \\
separation, \\
standardized \\
discharge of "three \\
wastes" \\
\end{tabular} & \begin{tabular}{|} 
Total recycle and \\
innocent \\
treatment of \\
"three wastes"
\end{tabular} & $\begin{array}{c}\text { Standardized } \\
\text { discharge of "three } \\
\text { wastes" }\end{array}$ & $\begin{array}{c}\text { Standardized } \\
\text { discharge of "three } \\
\text { wastes" }\end{array}$ & $\begin{array}{c}\text { Standardized } \\
\text { discharge of "three } \\
\text { wastes" }\end{array}$ & $\begin{array}{c}\text { Standardized } \\
\text { treatment of "three } \\
\text { wastes" }\end{array}$ & $\begin{array}{l}\text { Standardized } \\
\text { treatment of } \\
\text { "three wastes" }\end{array}$ \\
\hline & $\begin{array}{c}\text { Green coverage } \\
\text { ratio, up to } 100 \% \\
\text { of greenable area }\end{array}$ & $\begin{array}{c}\text { Green coverage } \\
\text { ratio, up to } 80 \% \\
\text { of greenable area }\end{array}$ & $\begin{array}{c}\text { Green coverage } \\
\text { ratio, up to } 100 \% \\
\text { of greenable area }\end{array}$ & $\begin{array}{l}\text { Green coverage } \\
\text { ratio, up to } 100 \% \\
\text { of greenable area }\end{array}$ & $\begin{array}{c}\text { Green coverage } \\
\text { ratio, up to } 100 \% \\
\text { of greenable area }\end{array}$ & $\begin{array}{l}\text { Green coverage } \\
\text { ratio, up to } 100 \% \\
\text { of greenable area }\end{array}$ & $\begin{array}{l}\text { Green coverage } \\
\text { ratio, up to } 100 \% \\
\text { of greenable area }\end{array}$ \\
\hline \multirow{4}{*}{ 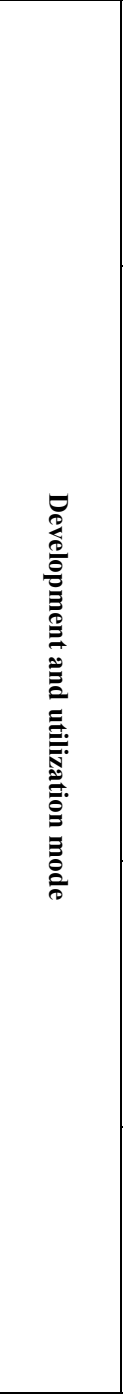 } & $\begin{array}{l}\text { Select resource- } \\
\text { conserving, } \\
\text { environmentally- } \\
\text { friendly mining } \\
\text { mode }\end{array}$ & $\begin{array}{c}\text { Recovery ratio of } \\
\text { oil and gas } \\
\text { recovery ratio is } \\
\text { not lower than } \\
\text { requirements of } \\
\text { development } \\
\text { planning } \\
\text { indicators. }\end{array}$ & $\begin{array}{l}\text { Select resource- } \\
\text { conserving, } \\
\text { environmentally- } \\
\text { friendly mining } \\
\text { mode }\end{array}$ & $\begin{array}{l}\text { Select resource- } \\
\text { conserving, } \\
\text { environmentally- } \\
\text { friendly mining } \\
\text { mode }\end{array}$ & $\begin{array}{l}\text { Select resource- } \\
\text { conserving, } \\
\text { environmentally- } \\
\text { friendly mining } \\
\text { mode }\end{array}$ & $\begin{array}{l}\text { Select resource- } \\
\text { conserving, } \\
\text { environmentally- } \\
\text { friendly mining } \\
\text { mode }\end{array}$ & $\begin{array}{l}\text { Select resource- } \\
\text { conserving, } \\
\text { environmentally- } \\
\text { friendly mining } \\
\text { mode }\end{array}$ \\
\hline & $\begin{array}{l}\text { In the central and } \\
\text { eastern regions, } \\
\text { strip or backfilling } \\
\text { mining is in } \\
\text { principle adopted, } \\
\text { with no need of } \\
\text { carrying gangues } \\
\text { out of wells. }\end{array}$ & \begin{tabular}{|c|} 
Leakage \\
prevention shall \\
be conducted \\
during storage \\
and \\
transportation of \\
oil and gas. \\
Leakage \\
prevention and \\
underground \\
water monitoring \\
shall be \\
conducted on \\
development, \\
storage and \\
transportation \\
sites of oil and \\
gas. \\
\end{tabular} & $\begin{array}{c}\text { Mining mode of } \\
\text { underground mine } \\
\text { gives priority to } \\
\text { backfilling mining } \\
\text { technology. Mining } \\
\text { mode of open-pit } \\
\text { mine shall meet the } \\
\text { requirements for } \\
\text { ecological } \\
\text { construction and } \\
\text { environmental } \\
\text { protection. }\end{array}$ & $\begin{array}{c}\text { It is suggested to } \\
\text { use backfilling } \\
\text { mining technology. }\end{array}$ & $\begin{array}{c}\text { Select reasonable } \\
\text { advanced mining } \\
\text { methods, such as } \\
\text { open-pit and } \\
\text { underground } \\
\text { mining technology, } \\
\text { whole tailings } \\
\text { backfilling mining } \\
\text { technology, etc. }\end{array}$ & $\begin{array}{l}\text { Open-pit mining } \\
\text { gives priority to } \\
\text { internal discharge } \\
\text { mode in priority; } \\
\text { underground } \\
\text { mining gives } \\
\text { priority to } \\
\text { backfilling mining } \\
\text { method. }\end{array}$ & $\begin{array}{l}\text { Use advanced } \\
\text { processing } \\
\text { technology, } \\
\text { technique and } \\
\text { equipment. }\end{array}$ \\
\hline & $\begin{array}{c}\text { Proper disposal } \\
\text { ratio of solid } \\
\text { wastes, such as } \\
\text { gangue, shall reach } \\
100 \% .\end{array}$ & & $\begin{array}{c}\text { Proper disposal } \\
\text { ratio of solid } \\
\text { wastes shall reach } \\
100 \% \text {; wastewater } \\
\text { treatment shall } \\
\text { reach the standard. }\end{array}$ & \begin{tabular}{|c|} 
Proper disposal \\
ratio of solid \\
wastes, such as \\
cyanidation \\
tailings, shall reach \\
$100 \%$; wastewater \\
treatment shall \\
reach the standard.
\end{tabular} & \begin{tabular}{|c|} 
Proper disposal \\
ratio of solid \\
wastes shall reach \\
$100 \%$
\end{tabular} & $\begin{array}{c}\text { Proper disposal } \\
\text { ratio of solid } \\
\text { wastes shall reach } \\
100 \% \text {; wastewater } \\
\text { treatment shall } \\
\text { reach the standard. }\end{array}$ & \\
\hline & $\begin{array}{l}\text { Fulfill obligations } \\
\text { in restoration, } \\
\text { governance and } \\
\text { land reclamation of } \\
\text { geological } \\
\text { environment of } \\
\text { mines }\end{array}$ & $\begin{array}{c}\text { Fulfill } \\
\text { obligations in } \\
\text { land reclamation, } \\
\text { with a } \\
\text { reclamation ratio } \\
\text { of } 100 \% .\end{array}$ & $\begin{array}{c}\text { Fulfill obligations } \\
\text { in restoration, } \\
\text { governance and } \\
\text { land reclamation of } \\
\text { geological } \\
\text { environment of } \\
\text { mines }\end{array}$ & $\begin{array}{c}\text { Fulfill obligations } \\
\text { in restoration, } \\
\text { governance and } \\
\text { land reclamation of } \\
\text { geological } \\
\text { environment of } \\
\text { mines }\end{array}$ & $\begin{array}{c}\text { Fulfill obligations } \\
\text { in restoration, } \\
\text { governance and } \\
\text { land reclamation of } \\
\text { geological } \\
\text { environment of } \\
\text { mines }\end{array}$ & $\begin{array}{l}\text { Fulfill obligations } \\
\text { in restoration, } \\
\text { governance and } \\
\text { land reclamation of } \\
\text { geological } \\
\text { environment of } \\
\text { mines }\end{array}$ & $\begin{array}{c}\text { Fulfill } \\
\text { obligations in } \\
\text { restoration, } \\
\text { governance and } \\
\text { land reclamation } \\
\text { of geological } \\
\text { environment of } \\
\text { mines }\end{array}$ \\
\hline
\end{tabular}




\begin{tabular}{|c|c|c|c|c|c|c|c|}
\hline 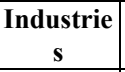 & Coal & $\begin{array}{c}\text { Petroleum and } \\
\text { natural gas }\end{array}$ & $\begin{array}{l}\text { Non-ferrous } \\
\text { metals }\end{array}$ & Gold & Metallurgy & Chemicals & Non-metal \\
\hline \multirow{2}{*}{ 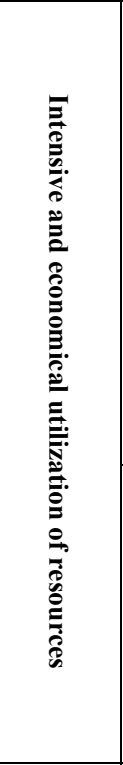 } & $\begin{array}{c}\text { Conduct integrated } \\
\text { assessment of coal } \\
\text { and its } \\
\text { paragenic/associate } \\
\text { d resources, and } \\
\text { use reasonable } \\
\text { utilization mode } \\
\text { and disposal } \\
\text { technique, thereby } \\
\text { guaranteeing } \\
\text { integrated } \\
\text { utilization of } \\
\text { resources }\end{array}$ & \begin{tabular}{|} 
Conduct \\
integrated \\
assessment, \\
development and \\
utilization of \\
associated \\
resources of oil \\
and gas
\end{tabular} & \begin{tabular}{|c|} 
Conduct integrated \\
assessment of non- \\
ferrous mineral \\
resources and their \\
paragenic/associate \\
$\mathrm{d}$ resources, use \\
reasonable \\
utilization mode \\
and disposal \\
technique, thereby \\
guaranteeing \\
integrated \\
utilization of \\
resources \\
\end{tabular} & $\begin{array}{c}\text { Conduct integrated } \\
\text { assessment of gold } \\
\text { and its } \\
\text { paragenic/associate } \\
\text { d resources, use } \\
\text { reasonable } \\
\text { utilization mode } \\
\text { and disposal } \\
\text { technique, thereby } \\
\text { guaranteeing } \\
\text { integrated } \\
\text { utilization of } \\
\text { resources }\end{array}$ & $\begin{array}{c}\text { Strengthen } \\
\text { reasonable } \\
\text { utilization of } \\
\text { metallurgical } \\
\text { mineral resources } \\
\text { and their } \\
\text { paragenic/associate } \\
\text { d useful } \\
\text { components, low- } \\
\text { grade ore, barren } \\
\text { rocks and tailings }\end{array}$ & $\begin{array}{c}\text { Conduct integrated } \\
\text { assessment of main } \\
\text { mineral varieties } \\
\text { and their } \\
\text { paragenic/associate } \\
\text { d resources, and } \\
\text { use reasonable } \\
\text { technology and } \\
\text { technique, thereby } \\
\text { guaranteeing } \\
\text { integrated recycle } \\
\text { of their } \\
\text { paragenic/associate } \\
\text { d resources } \\
\end{array}$ & \begin{tabular}{|} 
Graded \\
utilization, high- \\
quality \\
utilization and \\
integrated \\
utilization of \\
resources
\end{tabular} \\
\hline & $\begin{array}{l}\text { Classified disposal } \\
\text { and reasonable } \\
\text { utilization of solid } \\
\text { wastes; recycle rate } \\
\text { of wastewater up } \\
\text { to } 85 \% \text { and above. }\end{array}$ & $\begin{array}{c}\text { Mining water } \\
\text { resources based } \\
\text { on utilization of } \\
\text { oilfield; intensive } \\
\text { and economical } \\
\text { utilization of } \\
\text { land resources. }\end{array}$ & $\begin{array}{c}\text { Classified disposal } \\
\text { and reasonable } \\
\text { utilization of solid } \\
\text { wastes; full } \\
\text { utilization of } \\
\text { wastewater. }\end{array}$ & $\begin{array}{c}\text { Classified disposal } \\
\text { and reasonable } \\
\text { utilization of solid } \\
\text { wastes; recycle rate } \\
\text { of mineral dressing } \\
\text { wastewater up to } \\
85 \% \text { and above. }\end{array}$ & $\begin{array}{c}\text { Classified disposal } \\
\text { and reasonable } \\
\text { utilization of solid } \\
\text { wastes; recycle rate } \\
\text { of mineral dressing } \\
\text { wastewater up to } \\
85 \% \text { and above. }\end{array}$ & $\begin{array}{c}\text { Classified disposal } \\
\text { and reasonable } \\
\text { utilization of solid } \\
\text { wastes; recycle rate } \\
\text { of mineral dressing } \\
\text { wastewater up to } \\
85 \% \text { and above. }\end{array}$ & $\begin{array}{c}\text { Classified } \\
\text { disposal and } \\
\text { reasonable } \\
\text { utilization of } \\
\text { solid wastes; } \\
\text { recycle rate of } \\
\text { mineral dressing } \\
\text { wastewater up to } \\
85 \% \text { and above. }\end{array}$ \\
\hline \multirow[t]{2}{*}{ 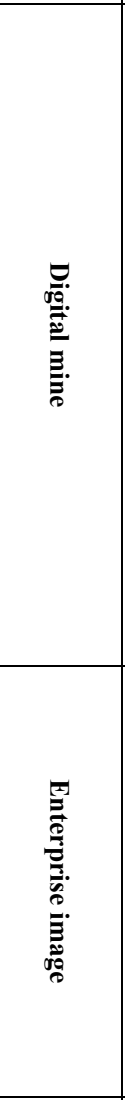 } & $\begin{array}{l}\text { Modernization of } \\
\text { production } \\
\text { technology and } \\
\text { technical } \\
\text { equipment; } \\
\text { automation of coal } \\
\text { mining; } \\
\text { informationization } \\
\text { of production } \\
\text { management; } \\
\text { establishment of } \\
\text { industry- } \\
\text { university-institute } \\
\text { sci-tech innovation } \\
\text { platform. }\end{array}$ & \begin{tabular}{|} 
Modernization of \\
technical \\
equipment; \\
digitization of \\
production \\
monitoring; \\
informationizatio \\
n of operating \\
management; \\
establishment of \\
industry- \\
university- \\
institute sci-tech \\
innovation \\
platform.
\end{tabular} & \begin{tabular}{|} 
Modernization of \\
production \\
technology and \\
technical \\
equipment; \\
mechanization of \\
mining, automation \\
of dressing and \\
smelting \\
technique; \\
informationization \\
of production \\
management; \\
establishment of \\
industry- \\
university-institute \\
sci-tech innovation \\
platform.
\end{tabular} & \begin{tabular}{|} 
Modernization of \\
production \\
technology and \\
technical \\
equipment; \\
mechanization of \\
mining, automation \\
of dressing and \\
smelting \\
technique; \\
informationization \\
of production \\
management; \\
establishment of \\
industry- \\
university-institute \\
sci-tech innovation \\
platform.
\end{tabular} & \begin{tabular}{|} 
Modernization of \\
production \\
technology and \\
technical \\
equipment; \\
mechanization of \\
mining, automation \\
of dressing and \\
smelting \\
technique; \\
informationization \\
of production \\
management; \\
establishment of \\
industry- \\
university-institute \\
sci-tech innovation \\
platform.
\end{tabular} & \begin{tabular}{|} 
Modernization of \\
production \\
technology and \\
technical \\
equipment; \\
mechanization of \\
mining, automation \\
of dressing and \\
smelting \\
technique; \\
informationization \\
of production \\
management; \\
integration of \\
industry- \\
university-institute \\
sci-tech \\
innovation.
\end{tabular} & $\begin{array}{l}\text { Modernization of } \\
\text { production } \\
\text { technology and } \\
\text { technical } \\
\text { equipment; } \\
\text { mechanization of } \\
\text { mining, } \\
\text { automation of } \\
\text { dressing and } \\
\text { smelting } \\
\text { technique; } \\
\text { informationizatio } \\
\text { n of production } \\
\text { management; } \\
\text { establishment of } \\
\text { industry- } \\
\text { university- } \\
\text { institute sci-tech } \\
\text { innovation } \\
\text { platform. }\end{array}$ \\
\hline & $\begin{array}{l}\text { Distinctive } \\
\text { enterprise culture } \\
\text { characteristics; } \\
\text { honest operation; } \\
\text { good operating } \\
\text { benefits; employee } \\
\text { satisfaction, no less } \\
\text { than } 70 \% \text {, and } \\
\text { satisfaction of the } \\
\text { masses in mining } \\
\text { area, no less than } \\
65 \% .\end{array}$ & \begin{tabular}{|c|} 
Enterprise \\
culture with \\
different regional \\
characteristics; \\
honest operation; \\
good operating \\
benefits; \\
employee \\
satisfaction and \\
satisfaction of \\
the masses in \\
mining area, no \\
less than $70 \%$.
\end{tabular} & \begin{tabular}{|} 
Distinctive \\
enterprise culture \\
characteristics; \\
honest operation; \\
good operating \\
benefits; employee \\
satisfaction and \\
satisfaction of the \\
masses in mining \\
area, no less than \\
$70 \%$.
\end{tabular} & $\begin{array}{c}\text { Distinctive } \\
\text { enterprise culture } \\
\text { characteristics; } \\
\text { honest operation; } \\
\text { good operating } \\
\text { benefits; employee } \\
\text { satisfaction and } \\
\text { satisfaction of the } \\
\text { masses in mining } \\
\text { area, no less than } \\
70 \% .\end{array}$ & $\begin{array}{c}\text { Distinctive } \\
\text { enterprise culture } \\
\text { characteristics; } \\
\text { honest operation; } \\
\text { good operating } \\
\text { benefits; employee } \\
\text { satisfaction and } \\
\text { satisfaction of the } \\
\text { masses in mining } \\
\text { area, no less than } \\
70 \% .\end{array}$ & $\begin{array}{c}\text { Distinctive } \\
\text { enterprise culture } \\
\text { characteristics; } \\
\text { honest operation; } \\
\text { good operating } \\
\text { benefits; employee } \\
\text { satisfaction and } \\
\text { satisfaction of the } \\
\text { masses in mining } \\
\text { area, no less than } \\
70 \% \text {. }\end{array}$ & $\begin{array}{c}\text { Distinctive } \\
\text { enterprise culture } \\
\text { characteristics; } \\
\text { honest operation; } \\
\text { good operating } \\
\text { benefits; } \\
\text { employee } \\
\text { satisfaction and } \\
\text { satisfaction of } \\
\text { the masses in } \\
\text { mining area, no } \\
\text { less than } 70 \% .\end{array}$ \\
\hline & \multicolumn{7}{|c|}{$\begin{array}{c}\text { Mine shall be an independent mine with a valid mining license. New mine has normally produced for at least one year. Remaining mining } \\
\text { years of productive mine shall be no less than five years, and it operates normally. }\end{array}$} \\
\hline Е.”. & \multicolumn{7}{|c|}{$\begin{array}{l}\text { In recent three years, the mine has not been subject to administrative penalties by the departments related to natural resources and } \\
\text { ecological environment, and the mining right owner has not been included in the anomaly list. }\end{array}$} \\
\hline
\end{tabular}




\section{Contents of remote sensing monitoring}

According to national relevant notifications and specifications ${ }^{[1-6]}$, green mines shall be some industrial leaders in six sectors, such as mining area environment, resources development mode, integrated utilization of resources, energy conservation and emission reduction, sci-tech innovation and informationization, enterprise management and enterprise image. By comparing construction requirements for different types of green mines, according to application status of remote sensing technology in natural resources survey monitoring work, it is recommended to carry out remote sensing survey and monitoring of selection conditions and qualified conditions of green mines in such sectors as access conditions, appearances and features of mine, ecological environmental protection, energy conservation and emission reduction, harmony of mineral estate, etc., which can provide technical support for selection and supervision of green mines (Table 2).

Tab.2 Primary Factors for Preliminary Screening of Candidate Mines and Annual Monitoring of Green Mines

\begin{tabular}{|c|c|c|c|}
\hline Type of factor & Name of factor & Standard requirements & Monitoring focuses \\
\hline \multirow{4}{*}{$\begin{array}{l}\text { Access } \\
\text { conditions }\end{array}$} & Independent mine & With a valid mining license & With a license, within a valid period \\
\hline & $\begin{array}{l}\text { Normal production } \\
\text { time }\end{array}$ & One year & One-year mining duration \\
\hline & Illegal mining & Hasn't mined within three years & $\begin{array}{c}\text { Whether there existed illegal mining within } \\
\text { three years }\end{array}$ \\
\hline & Nature reserve & $\begin{array}{l}\text { Mining area is not within nature } \\
\text { reserve. }\end{array}$ & $\begin{array}{l}\text { There is no crossover between mining right } \\
\text { boundary and nature reserve boundary. }\end{array}$ \\
\hline \multirow{3}{*}{$\begin{array}{l}\text { Appearances } \\
\text { and features of } \\
\text { mine }\end{array}$} & $\begin{array}{l}\text { Functional partition } \\
\text { of mining area }\end{array}$ & $\begin{array}{l}\text { Various areas, such as production } \\
\text { area, management area, living } \\
\text { area, ecological preservation area, } \\
\text { etc. are clearly defined. }\end{array}$ & $\begin{array}{c}\text { Functional partitions are obvious; there is no } \\
\text { solid waste within management area and } \\
\text { living area. }\end{array}$ \\
\hline & $\begin{array}{c}\text { Construction } \\
\text { without permission }\end{array}$ & No temporary building & $\begin{array}{l}\text { No metal building and temporary plant } \\
\text { building }\end{array}$ \\
\hline & $\begin{array}{l}\text { Mining area } \\
\text { greening }\end{array}$ & Green coverage ratio $100 \%$ & $\begin{array}{c}\text { Greenable areas in the mining area have been } \\
\text { greened. }\end{array}$ \\
\hline \multirow{3}{*}{$\begin{array}{c}\text { Ecological } \\
\text { environmental } \\
\text { protection }\end{array}$} & $\begin{array}{l}\text { Roads in the mining } \\
\text { area }\end{array}$ & $\begin{array}{l}\text { Hardening of drainage ditch in } \\
\text { the inner side, planting of border } \\
\text { trees in the outer side }\end{array}$ & $\begin{array}{l}\text { Hardening of inner side of roads, planting of } \\
\text { border trees in the outer side }\end{array}$ \\
\hline & Solid wastes & $\begin{array}{l}\text { Implement land reclamation, } \\
\text { greening or beautification }\end{array}$ & Restoration and governance measures \\
\hline & $\begin{array}{c}\text { Restoration and } \\
\text { governance of illegal } \\
\text { lands in previous } \\
\text { years }\end{array}$ & $\begin{array}{l}\text { Restoration and governance of } \\
\text { previous illegal lands }\end{array}$ & $\begin{array}{l}\text { Whether lands destroyed by the mine beyond } \\
\text { range of mining right have been restored } \\
\text { governance. }\end{array}$ \\
\hline \multirow{2}{*}{$\begin{array}{c}\text { Energy } \\
\text { conservation } \\
\text { and emission } \\
\text { reduction }\end{array}$} & Wastewater & Standardized discharge & No water pollution \\
\hline & Barren rocks & Resource utilization & $\begin{array}{l}\text { Secondary processing evidence beside barren } \\
\text { rock pile }\end{array}$ \\
\hline \multirow{2}{*}{$\begin{array}{l}\text { Harmony of } \\
\text { mineral estate }\end{array}$} & Goaf collapse area & $\begin{array}{l}\text { Can't endanger basic farmland, } \\
\text { building construction and } \\
\text { important transportation facilities }\end{array}$ & $\begin{array}{c}\text { No basic farmland, building construction and } \\
\text { important transportation facilities are } \\
\text { destroyed. }\end{array}$ \\
\hline & $\begin{array}{l}\text { Water pollution } \\
\text { within residential } \\
\text { area }\end{array}$ & No pollution & $\begin{array}{l}\text { Whether water color and water quality in river } \\
\text { and pit-pond nearby residential area are } \\
\text { abnormal. }\end{array}$ \\
\hline
\end{tabular}

\section{Remote sensing monitoring method}

At present, because microwave remote sensing technology and hyperspectral remote sensing technology have not yet formed an application technology system, they didn't meet the actual needs in the mine monitoring work. So we use home-made high resolution (spatial resolution above $2.5 \mathrm{~m}$ ) remote sensing data as main data source, supplemented by UAV remote sensing data, conducting visual interpretation and human-computer interactive interpretation This is still a common method for preliminary screening of candidate mines and annual monitoring of green mines. As shown in Figure 1, relevant technical procedures, according to experimental research in some mines in Jiangxi Province, Hunan Province, Fujian Province, etc., can be divided into three stages: preparation of remote sensing data, comparison of monitoring factors, online validation and review application of data. 


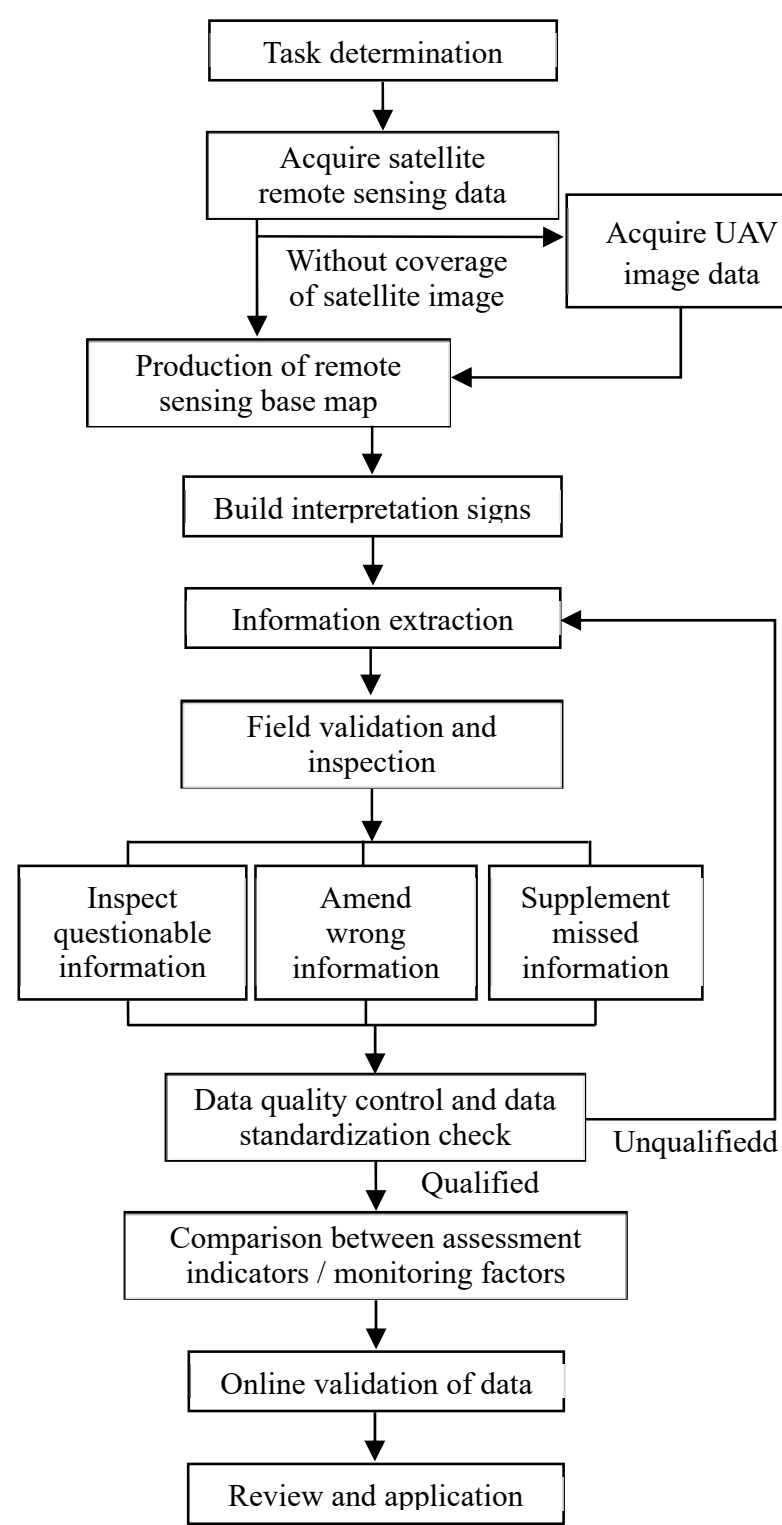

Fig.1 Remote Sensing Workflow for Preliminary Screening of Candidate Mines and Annual Monitoring of Green Mines

\subsection{Data preparation}

The data preparation stage includes the following steps: production of remote sensing base map, information extraction, field validation, quality check of interpretation data, etc.

The remote sensing base map is a foundation for preliminary screening of candidate mines and annual monitoring of green mines. Appropriate data shall be selected to conduct production of remote sensing base map. Selection and monitoring of open-pit mining mines can use remote sensing data with a spatial resolution above $2.5 \mathrm{~m}$, because mine ground objects have total area of more than $100 \mathrm{~m}^{2}$. Selection and monitoring of underground mining mines shall use remote sensing data with a spatial resolution above $1.0 \mathrm{~m}$, because it needs to recognize ground objects, such as well-head, adit collar, etc. (total area is in general $16 \mathrm{~m}^{2}$ or so.) Plane-coordinate system of remote sensing base map shall use the 2000 Chinese Geodetic Coordinate System; Height system uses the 1985 National Height Datum; Gauss-Kruger projection mode ( $3^{\circ}$ zone) can be adopted. Image shall maintain optimal resolution of raw image data.

Information extraction, field validation and quality check of interpretation data work shall be executed according to Regulation on Remote Sensing Monitoring of Mining Exploration (DZ/T0266) ${ }^{[7]}$. Information that is clearly marked and recognized on the image need no field validation.

\subsection{Comparison between assessment indicators I monitoring factors}

With ArcGIS software as basis, a "Green Mine Remote Sensing Monitoring Information System" is built to conduct a unified management over survey monitoring information and relevant management information (such as mining right information, nature reserve information, etc.) from remote sensing base map of candidate mines and green mines. On this basis, preliminary comparison or recognition of assessment indicators of candidate mines and green mines (or called monitoring factors) is carried out.

\subsubsection{Comparison between access condition factors}

Access conditions can be monitored whether independent mine is valid, whether mine produces normally, and whether there were illegal mining actions within three years. Taking a tungsten ore mine in Fujian Province shown in Figure 2A as an example, open mining pits are uniformly distributed within range of mining right, mine mining site, refuse dump, mine construction, etc. are complete, mining pit road and refuse dump in its north side are in use; therefore, the mine can meet conditions for access and annual inspection of green mine. Taking a nonmetal mine in Jiangxi Province shown in Figure 2B as an example, periphery of open-pit stope, especially of the east and west sides, is beyond range of mining right, and illegal parts have not yet been restored governance; therefore, the mine can meet access conditions of green mine. 

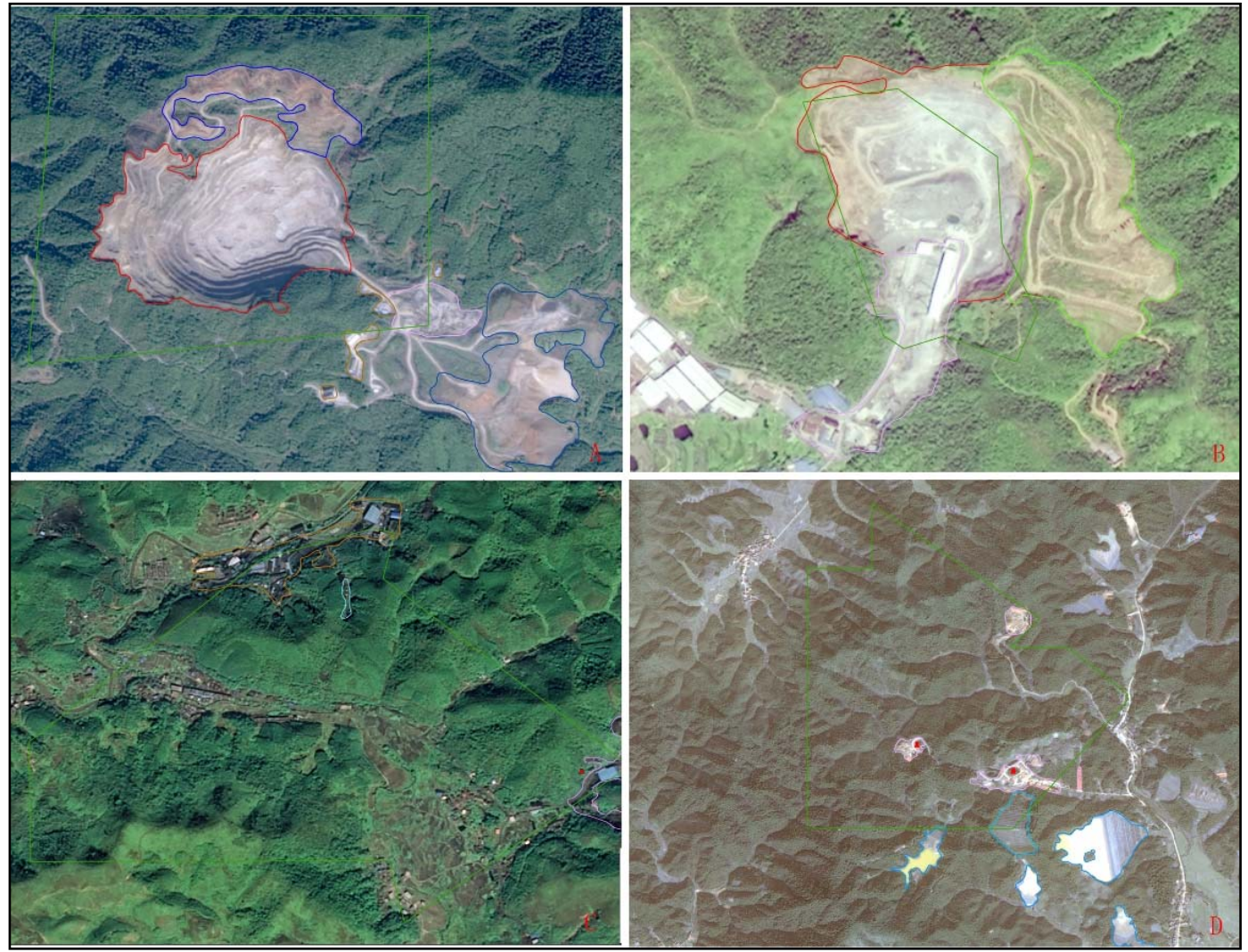

Legend

Ming rights

Stope (in use)

Mineral dressing site(in use)
Well-head (adit collar)

Tailing reservoir (in use)

$\neg$ Tailing reservoir (abandoned)
Internal refuse dump (in use)

External refuse dump (in use)

Mine construction (in use)

Fig.2 An Example for Comparison between Monitoring Factors

\subsubsection{Comparison between appearances and features factors of mine}

In terms of appearances and features of mine, monitor whether functional partitions of mining area are defined, whether there is construction without permission, and whether greenable area is greened. Taking a coal mine in Hunan Province shown in Figure $2 \mathrm{C}$ as an example, production well / adit collar, coal dressing site and gangue pile are orderly stacked, functional partitions of mining area are defined; coal mining collapse area has been or is being restored governance; therefore, the coal meets conditions for selection or annual inspection of appearances and features of green mine. Taking a gold mine in Jiangxi Province shown in Figure 2D as an example, images in the vicinity of production well /adit collar, mineral dressing site, etc. are chaotic, and solid wastes are stacked downslope disorderly; therefore, the mine can't meet conditions for appearances and features of green mine.

\subsubsection{Comparison between ecological environmental protection factors}

Ecological environmental protection can be monitored whether inner side of the roads in the mining area can be hardened, and outer side can be planted with border trees, whether solid wastes have measures of restoring governance, and whether previous illegal lands have been restored governance. Taking a lead zinc mine in Hunan Province shown in Figure 3 as an example, the tailing reservoir of the mine has been covered with soil and restored the green, and vegetation growth is basically coordinated with the surrounding environment; the solid waste pile has been partially covered with soil and grass on the top, and partially restored on the edge; inside of road to the mine has been hardened by field verification, which basically has met conditions for ecological environmental protection of green mine. 


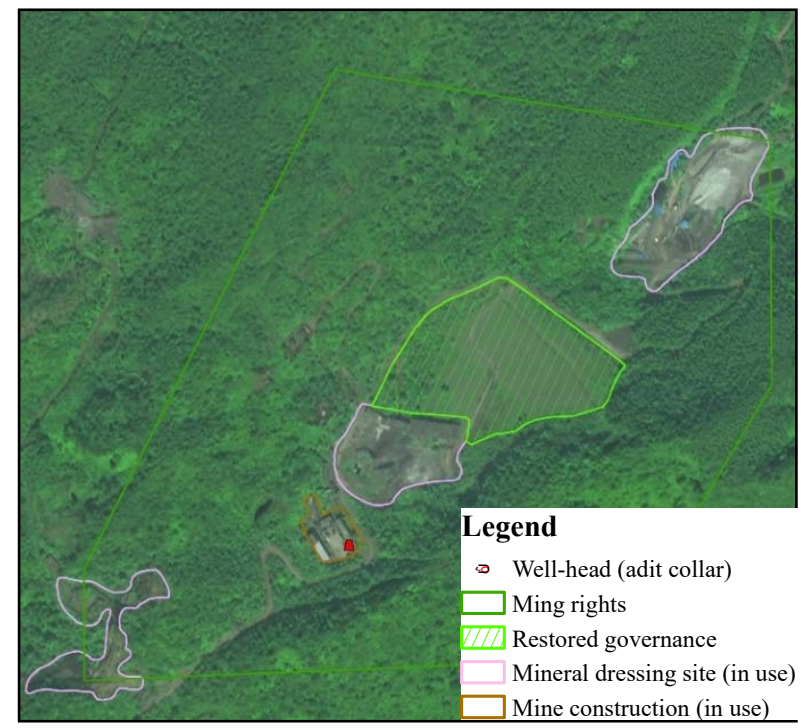

Fig.3 An Example for Comparison between Ecological Environmental Protection Factors

\subsubsection{Comparison between energy conservation and emission reduction factors}

Energy conservation and emission reduction can be monitored whether mine wastewater reaches discharge standard (the water body around the mining area is not polluted.), and whether the barren rocks are utilized. Taking a gold mine in Jiangxi shown in Figure 2D, the accumulation of wastewater in the tailing reservoir is normal, there is no abnormal water flow on the surface, there is no abnormal vegetation in the low-lying areas, there is no leakage at the lower reach of tailing reservoir on the surface, and there is no anomaly in the discharge of mining wastewater; therefore, the mine can meet conditions for energy conservation and emission reduction of mines.

\subsubsection{Comparison between mineral estate harmony factors}

Harmony of mineral estate can be monitored whether mine geological disasters endanger basic farmland, building construction and important transportation facilities, whether water body in residential area is abnormal in water color, water quality, etc. Taking a coal mine in Hunan Province shown in Figure $2 \mathrm{C}$ an example, the goaf collapse area in the Northwest, where vegetation has been restored after years of governance, has basically no impact on building construction and important transportation facilities in the mining area; the water color of the water system flowing through the mining area has not changed; therefore, the mine can basically meet conditions for harmony of mineral estate of green mine.

\subsection{Online validation and review application of data}

Through online validation function of information system, remote sensing monitoring result can be interchanged with review department and mine enterprises; through the work process including inspection, feedback / amendment, reinspection, re-feedback / re-amendment and other, monitoring organization and review department, mine enterprise, etc. jointly validate remote sensing monitoring result; full flow record of validation and amendment process can ensure the traceability of result formation process and responsibility. Validated result data shall be reviewed by competent authority, and directly submitted for application.

\section{Conclusions}

Constructing green mine is an effective approach to advance intensive and economical utilization of natural resources. Through integrated analysis on construction requirements and assessment indicators of green mines, main content of remote sensing monitoring of green mines shall include the following indicators: whether the mine continues to be mined in the current year, whether the mine had any illegal mining action in recent years, whether the mine environment is clean, whether the solid wastes are properly disposed, whether the wastewater is discharged in accordance with the standard, whether the mine area which shall be restored governance has been governed, and whether the barren rocks have achieved resource utilization.

The monitoring test results of some mines in Hunan Province, Jiangxi Province and Fujian Province show that not all the assessment indicator values can be obtained through remote sensing; however, remote sensing technology can be used in monitoring selection conditions and qualified conditions of green mine in such sectors as access conditions, appearances and features of mine, ecological environmental protection, energy conservation and emission reduction and harmony of mineral estate, which will provide technical support for selection and supervision of green mine.

It is suggested to increase the application of microwave remote sensing technology and hyperspectral remote sensing technology in the green mine monitoring work, in order to further determine goaf subsidence range and environment pollution area, which can provide the solid technical support for annual assessment of green mines.

\section{Acknowledgements}

This paper is supported by Programs of China Geological Survey (DD20190705, DD20190511). Thank for guidance and help in the work and writing process from Li Xianhai, Wu Shangkun, HouHuali and other experts.

\section{References}

1. Ministry of Natural Resources of the People's Republic of China,Green Mine Construction Specification of Onshore Petroleum and Natural Gas Mine,Beijing: Ministry of Natural Resources of the People's Republic of China, (2018) 
2. Ministry of Natural Resources of the People's Republic of China,Green Mine Construction Specification of Coal Industry,Beijing: Ministry of Natural Resources of the People's Republic of China, (2018)

3. Ministry of Natural Resources of the People's Republic of China,Green Mine Construction Specification of Metallurgical Industry,Beijing: Ministry of Natural Resources of the People's Republic of China, (2018)

4. Ministry of Natural Resources of the People's Republic of China,Green Mine Construction Specification of Non-ferrous Industry,Beijing: Ministry of Natural Resources of the People's Republic of China, (2018)

5. Ministry of Natural Resources of the People's Republic of China,Green Mine Construction Specification of Gold Industry,Beijing: Ministry of Natural Resources of the People's Republic of China, (2018)

6. Ministry of Natural Resources of the People's Republic of China,Green Mine Construction Specification of Non-metallic Minerals Industry, Beijing: Ministry of Natural Resources of the People's Republic of China, (2018)

7. Ministry of Land and Resources of the People's Republic of China,Green Mine Construction Specification of Non-metallic Minerals Industry ,Beijing: Ministry of Land and Resources of the People's Republic of China, (2014) 